\title{
PERANAN AUDIT INTERNAL UNTUK MENINGKATKAN EFISIENSI PRODUKSI LISTRIK DAN PENERIMAAN KAS PLTD WILAYAH DISTRIBUSI JAWA BARAT DAN BANTEN PADA PT PLN (PERSERO)
}

\author{
Retno Martanti Endah Lestari \\ Dosen Tetap Fakultas Ekonomi \\ Universitas Pakuan \\ Fahmi Kaffata Aqieda \\ Mahasiswa Fakultas Ekonomi \\ Universitas Pakuan
}

\begin{abstract}
ABSTRAK
Adapun tujuan penelitian yang hendak dicapai penulis adalah untuk menguji secara empiris peranan audit internal untuk meningkatkan produksi listrik dan penerimaan kas. Pengujian dilakukan secara parsial dan simultan (bersama-sama antara variabel independen Audit Internal, seperti pemeriksaan operasional, pelaporan rekomendasi hasil audit, dan pengawasan atas tindak lanjut.

Populasi penelitian yang diteliti adalah Fungsi Pembangkit PT PLN (Persero) pada tahun 2009-2010. Sampel penelitian berjumlah 1 unit pembangkit yakni PLTD wilayah distribusi Jawa Barat dan Banten yang dipilih menggunakan metode purposive sampling dengan periode pengamatan selama 2 tahun. Pengumpulan data dilakukan dengan riset kepustakaan dan pengumpulan data sekunder dari PT PLN (Persero). Data kemudian diolah dengan menggunakan perbandingan dan rasio.

Berdasarkan hasil pengujian terhadap 1 unit pembangkit yakni PLTD wilayah distribusi Jawa Barat dan Banten yang dipilih menggunakan metode purposive sampling dengan periode pengamatan selama 2 tahun menggunakan perbandingan dan rasio menunjukkan bahwa kemampuan PLTD wilayah distribusi Jawa Barat dan Banten itu sendiri tidak dapat memenuhi kebutuhan listrik masyarakat Jawa Barat dan Banten itu sendiri sehingga untuk dapat memenuhi permintaan kebutuhan listrik dari masyarakat maka PLN wilayah distribusi Jawa Barat dan Banten mendapatkan pasokan listrik sebesar $98 \%$ dari unit pembangkit lain yang berada baik di pulau Jawa maupun di luar pulau Jawa. Hal ini mengakibatkan terjadinya over capacity pada unit pembangkit yang memberikan pasokan listrik kepada PLN wilayah distribusi Jawa Barat dan Banten itu sendiri yang menyebabkan terjadinya penurunan daya mampu produksi listrik sehingga mengakibatkan pembelian bahan bakar menjadi lebih besar dari yang sudah dianggarkan. Seharusnya disinilah peranan audit internal untuk dapat memberikan rekomendasi yang dapat menjadi sebuah solusi bagi manajemen untuk mengatasi permasalahan tersebut. Melalui penelitian diketahui secara empiris bahwa peranan satuan pengendalian intern atau audit internal sagat penting walaupun secara realisasinya masih dirasakan sangat minimal.
\end{abstract}

Kata kunci: Audit Internal, Efektivitas, Efisinesi, dan Ekonomisasi 


\section{Pendahuluan}

Pada umumnya dalam perusahaan yang telah maju dan ruang lingkupnya besar baik BUMN maupun BUMS secara ideal tujuannya adalah untuk meningkatkan ekonomisasi, efisiensi, dan efektivitas agar kelangsungan hidup perusahaan dapat terjaga. Dalam upaya untuk meningkatkan efisiensi perusahaan menggunakan alat untuk mengarahkan agar tujuan perusahaan dapat tercapai yakni dengan melakukan pengendalian internal.

Auditor internal dalam kenyataannya sangat mengalami kesulitan untuk berusaha meningkatkan efisiensi perusahaan terutama dalam pengawasan terhadap pengendalian internal agar manajemen tidak mengabaikan faktor pengendalian tersebut. Audit operasional merupakan alat bantu auditor dalam menguji dan mengevaluasi pengendalian pada manajemen dalam melakukan semua kegiatan perusahaan, sehingga kegiatan-kegiatan yang dilakukan oleh manajemen perusahaan dapat berjalan dengan efisien serta dapat mencapai tujuan yang telah direncanakan.

PLN (Persero) yang terletak di Jalan Truno Joyo Blok M 1/135, Kebayoran Baru. Jakarta Selatan merupakan suatu perusahaan yang bergerak dalam bidang jasa penyedia energi listrik. PT. PLN (Persero) ini mempunyai masalah dalam pemeriksaan operasional dan pengawasan terhadap tindak lanjut yang sangat kurang pada produksi yang merupakan sumber utama produksi dan penerimaan kas perusahaan, serta membuat manajemen mengabaikan pengendalian intern, sehingga menyebabkan kurangnya tingkat efisiensi dalam produktivitas karyawan dan pengelolaan anggaran.

Dari beberapa data penjualan, biaya pembelian bahan bakar, dan subsidi pemerintah menunjukkan dari tahun 2006-2010 persentase kenaikan penjualan lebih kecil dibandingkan dengan persentase kenaikan biaya pembelian bahan bakar dan persentase kenaikan subsidi, hal ini memperlihatkan bahwa terjadinya pemborosan pada produksi yang terjadi dalam kurun waktu lima tahun. Selain itu berdasarkan audit dan review oleh Badan Pengawas Keuangan (BPK), dan Kantor Akuntan Publik Deloite tahun 2010 yang menyatakan adanya pelanggaran atas pengendalian intern pada PLTGU Gili Timur yakni bahan bakar yang seharusnya digunakan pada Pembangkit ini adalah gas, namun pada kenyataannya tahun 2010 Pembangkit ini menggunakan bahan bakar solar yang harganya lebih mahal dibandingkan dengan bahan bakar gas dan tentunya mengindikasikan tidak tercapainya keekonomisan, efektivitas, dan efisiensi pada PT. PLN (persero) sedangkan faktor-faktor tersebut merupakan penentu dari kelangsungan hidup perusahaan terutama pada produksi yang merupakan fungsi inti dan utama pada PT. PLN (Persero). Adapun tujuan penelitian ini 
adalah sebagai berikut: 1 . Untuk menguji secara empiris peranan audit internal atas fungsi produksi listrik dan penerimaan kas PLTD wilayah distribusi Jawa Barat dan Banten pada PT. PLN (Persero), 2. Untuk menguji secara empiris tingkat efisiensi pada produksi listrik dan penerimaan kas PLTD wilyah distribusi Jawa Barat dan Banten pada PT. PLN (Persero), dan 3. Untuk menguji secara empiris peranan audit internal dalam rangka meningkatkan efisiensi produksi listrik dan penerimaan kas PLTD wilayah distribusi Jawa Barat dan Banten pada PT. PLN (Persero).

\section{Metode Penelitian}

Jenis penelitian dalam penulisan skripsi ini adalah deskriptif eksploratif, metode penelitian yang digunakan dalam penulisan skripsi ini adalah studi kasus, teknik penelitian yang penulis gunakan dalam penyusunan skripsi ini adalah deskriptif kualitatif dan kuantitatif, prosedur yang digunakan dalam pengumpulan data adalah studi kepustakaan dan studi lapangan, seperti wawancara. Metode analisis yang digunakan oleh penulis adalah deskriptif kualitatif dan kuantitatif (non statistik).

\section{Hasil Penelitian}

\subsection{Efisiensi Produksi Listrik dan Realisasi Penerimaan Kas PLTD Disribusi Jawa} Barat dan Banten Pada PT PLN (Persero)

\subsubsection{Realisasi Pembelian Bahan Bakar Tahun ini Untuk Pembangkit dengan Realisasi Tahun Sebelumnya pada PT PLN (Persero)}

Dari data umum pembelian bahan bakar dapat dilihat bahwa total biaya pembelian bahan bakar jauh diatas pendapatan asli PT PLN itu sendiri. Dari sini terlihat bahwa setiap tahun PT PLN selalu mengalami kerugian pada kegiatan usahanya sehingga perlu selalu diberikan subsidi oleh pemerintah setiap tahunnya. Untuk mengetahui ketidakefisienan PT PLN terutama fungsi PLTD wilayah distribusi Jawa Barat dan Banten dapat dilihat dengan membandingkan antara kemampuan produksi listrik yang dimiliki oleh PLTD wilayah distribusi Jawa Barat dan Banten, penyaluran energy kepada pelanggan, pendapatan per kelompok pelanggan, pemakaian bahan bakar, harga satuan bahan bakar, dan piutang langganan.

\subsubsection{Perbandingan Realisasi Efisiensi Produksi Listrik dan Penerimaan Kas}

PLTD Distribusi Jawa Barat dan Banten Sebelum dan Sesudah Pemeriksaan Operasional Oleh Audit Internal pada PT PLN (Persero). 
Daya mampu atau kemampuan suatu unit pembangkit untuk memproduksi listrik tidak dapat memenuhi permintaan masyarakat. Hal ini mengharuskan PT PLN memberikan supply daya dari unit pembangkit lain yang berada diluar wilayah distribusi Jawa Barat dan Banten, namun hal ini mengakibatkan unit pembangkit lain yang mensupply listrik memproduksi listrik secara over capacity yang akibatnya tingkat kerusakan pada unit pembangkit menjadi lebih tinggi dan mempercepat tingkat kehausan mesin ditambah pemeliharaan unit pembangkit yang selalu terlambat dari jadwal yang telah ditetapkan. Adanya kehausan mesin maka energi listrik yang di produksi dengan jumlah bahan bakar yang sama menjadi lebih kecil sehingga PT PLN (Persero) harus membeli bahan bakar yang lebih banyak untuk dapat memenuhi kebutuhan akan listrik para pelanggannya dan hal ini mengakibatkan biaya yang harus dikeluarkan oleh PT PLN (Persero) menjadi lebih besar. Selain itu listrik yang dipasok oleh unit pembangkit lain diluar PLTD wilayah ditribusi Jawa Barat dan Banten akan mengalami susut energi dan electricity loss akibat kabel jaringan yang terlalu panjang sehingga hambatan yang dilalui oleh listrik pun menjadi besar. Sehingga untuk menutupi sisa kekurangan listrik maka PLN membeli listrik dari pihak swasta.

Jumlah pembelian bahan bakar dari tahun 2009 sampai dengan tahun 2010 meningkat sebesar $19,7 \%$. Peningkatan yang signifikan terjadi pada pembelian bahan bakar minyak bumi jenis HSD yang meningkat sebesar Rp 141,055,000.00. Hal ini sangat tidak efisien karena bertolak belakang dengan jumlah pembangkit listrik tenaga diesel yang justru berkurang sebanyak 7 unit pembangkit di seluruh Indonesia. Seharusnya adanya pengurangan unit pembangkit listrik tenaga diesel akan berimbas pada berkurangnya pembelian bahan bakar jenis minyak dan meningkatnya pembelian listrik dari pihak swasta. Namun ternyata realisasinya berbeda.

Perbandingan pendapatan dan piutang langganan dapat dilihat bahwa tingkat penerimaan kas dari aktivitas operasi cenderung dapat tertagih karena jumlah piutang yang tidak lebih dari $1 \%$ sehingga rata-rata kecepatan penagihannya piutangnya berjalan dengan baik dan cepat. Walaupun dari segi penerimaan kas cenderung tidak ada masalah, namun karena adanya pembebanan biaya yang melonjak mengakibatkan penerimaan kas dan labanya cenderung turun. Hal ini menyebabkan PT PLN (Persero) menderita kerugian dan diragukan kelangsungan hidupnya apabila subsidi yang diberikan pemerintah dicabut. 
Sistem penyaluran listrik yang sampai saat ini sebagian besar masih menggunakan sistem pasca bayar menambah jumlah beban produksi listrik PT PLN (Persero). Hal ini dikarenakan seringnya terjadi pemakaian over used dan pencurian kabel distribusi yang menyebabkan pasokan listrik kepada pelanggan menjadi berkurang yang berimbas semakin meningkatnya permintaan akan kebutuhan listrik pada masyarakat.

Rata-rata permintaan akan listrik terus meningkat hal ini mengakibatkan faktor beban yang harus ditanggung oleh unit-unit pembangkit yang dimiliki oleh PT PLN (Persero) menjadi semakin besar seiring dengan semakin meningkatnya faktor permintaan. Hal ini secepatnya harus diantisipasi oleh manajemen dari PT PLN (Persero), jika solusi alternatif masih belum dapat dilaksanakan maka kondisi ini akan terus berlanjut dan membuat laba perusahaan tidak maksimal.

\subsection{Evaluasi Terhadap Peranan Internal Audit Untuk Meningkatkan Efisiensi Produksi Listrik dan Penerimaan Kas PLTD Wilayah Distribusi Jawa Barat dan Banten Pada PT PLN (Persero)}

Ketidakefisiensian biaya pembelian bahan bakar pada produksi PT PLN (Persero) terlihat dari realisasi biaya pembelian bahan bakar HSD yang meningkat sebesar 19,7\% ditahun 2010 sedangkang unit pembangkit listrik untuk jenis bahan bakar ini justru berkurang, serta perbandingan realisasi biaya tahun 2010 lebih besar dibandingkan tahun 2009. hal ini terjadi karena ada pengeluaran biaya yang membengkak akibat harus pemeliharaan unit pembangkit yang sering kali lewat dari waktu yang sudah ditentukan sehingga membuat kehausan mesin unit pembangkit lebih cepat dari umur ekonomisnya pada unit pembangkit lain yang memasok listrik tambahan pada PLN wilayah distribusi Jawa Barat dan Banten, perbaikan dan penggantian komponen unit pembangkit yang berumur lama seringkali bukan dengan kualitas standar melainkan selalu dibawah standar yang pada akhirnya mengakibatkan daya mampu listrik yang diproduksi tidak dapat mencapai batas produksi normal sesuai dengan kapasitas terpasang dan cenderung terus menurun, apabila masalah ini tidak diatasi dengan baik maka akan menimbulkan kerugian bagi perusahaan karena laba yang dihasilkan tidak akan maksimal dan pada akhirya akan berpengaruh terhadap kelangsungan hidup perusahaan.

Biaya pembelian bahan bakar yang tidak sesuai dengan anggarannya dan ketentuannya akan dievaluasi kembali dan akan dicarikan solusi atas kelebihan biaya tersebut. Oleh karena 
itu dalam mengatasi permasalahan ini peranan pemeriksaan operasional oleh internal audit sangat dibutuhkan untuk membantu dan mengevaluasi pengendalian agar jumlah unit dan biaya yang dikeluarkan oleh perusahaan dapat lebih efisien. Dalam hal ini peran internal audit adalah memberikan rekomendasi-rekomendasi kepada manajeman apa saja yang harus diperbaiki, serta mendampingi dan mengevaluasi tindak lanjut yang dilakukan oleh manajemen, walaupun hak sepenuhnya untuk menjalankan tindak lanjut atas rekomendasi ada di tangan manajemen.

Hal ini perlu untuk dicermati karena permasalahan yang terjadi terletak cost centre terbesar PT PLN (Persero) sehingga pengaruhnya akan berdampak secara langsung baik pada laba perusahaan maupun bagi kelangsungan hidup perusahaan. Disinilah peran dari divisi audit internal yang harus cermat dalam menanggulangi permasalahan yang muncul, bukan hanya berdasarkan issue yang ada tetapi juga berdasarkan tingkat materil suatu unit terhadap kelangsungan hidup perusahaan yang menaunginya.

Proyek 10.000 MW yang direncanakan sebagai solusi alternative untuk mengatasi permasalahan ini pada realisasinya masih belum terwujud sedangkan pada tahun 2010 ini PT PLN (Persero) sudah kehilangan 6 unit pembangkitnya karena kerusakan yang terjadi akibat pemakaian yang berlebihan (Over Capacity Used).

Program listrik pra bayar yang merupakan suatu solusi untuk mengatasi pemakain listrik yang over capacity oleh pelanggan justru sangat kurang di promosikan. Padahal dengan adanya program listrik pra bayar ini sendiri PT PLN (Persero) dapat lebih efisien dalam memproduksi listrik karena pemakaian listrik dapat diukur serta dapat dibatasi dan cenderung konstan. Hal ini seharusnya menjadi fokus bagi satuan pengendalian intern untuk meningatkan dan mengawasi manajemen agar produksi listrik dapat lebih efisien.

\section{Kesimpulan}

PLN (Persero) dan berpedoman pada Undang-undang No.30 Tahun 2009. Menjalankan usaha penyediaan tenaga listrik yang mencakup:
a. Pembangkitan tenaga listrik.
b. Penyaluran tenaga listrik.
c. Distribusi tenaga listrik.
d. Perencanaan dan pembangunan sarana penyediaan tenaga listrik.
e. Pengembangan penyediaan tenaga listrik.
f. Penjualan tenaga listrik. 
1. PT PLN (Persero) dalam pengoperasiannya selalu berpegang pada Rancangan Kerja dan Anggaran Perusahaan yang mana pelaksanaanya sesuai dengan Undang-undang no 30 tahun 2009 tentang ketenagalistrikan

2. Internal Audit pada PT PLN (Persero) telah memprogramkan dan melaksanakan audit dalam tahun 2010 meliputi pemeriksaan dan penilaian atas kecukupan sistem pengendalian dan kinerja untuk meningkatkan efisiensi, efektifitas, dan ekonomisasi biaya operasi, audit keuangan, audit kepatuhan serta pemeriksaan lain sesuai kebutuhan.

3. Terdapat ketidakefisiensian biaya yang dapat diindikasikan dari selisih antara realisasi biaya pembelian bahan bakar yang melebihi anggaran dan ketentuan ditahun 2010 dan juga realisasi biaya tahun 2010 lebih besar dibandingkan tahun 2009. Hal tersebut disebabkan karena ada pengeluaran biaya yang membengkak akibat pemeliharaan unit pembangkit yang terlambat, perbaikan dan penggantian komponen unit pembangkit yang tidak sesuai dengan spesifikasi sehingga mengakibatkan kehausan mesin unit pembangkit lebih cepat dari umur ekonomisnya serta adanya pasokan ke listrik ke unit distribusi Jawa Barat dan Banten yang menyebabkan beban puncak unit pembangkit yang memasok listrik menjadi lebih besar.

4. Dampak dari kehausan mesin yang ditimbulkan dibagian unit pembangkit mengakibatkan tingkat kehilangan daya listrik pada PT PLN (Persero), kehilangan daya listrik tersebut diukur dari jumlah energi yang diproduksi dibandingkan dengan jumlah daya yang terjual ke pelanggan, kehilangan listrik diakibatkan adanya susut energy saat distribusi listrik dilakukan. Tingkat kehilangan daya listrik menjadi salah satu permasalahan yang akan menghambat realisasi penjualan secara maksimal, imbasnya akan berpengaruh kepada laba yang akan dihasilkan oleh perusahaan.

5. Dilihat dari seluruh kondisi PT PLN (Persero) dalam kegiatan operasinya telah dilengkapi dengan unsur-unsur pengawasan prosedur dan pengawasan tersebut dapat meminimalkan risiko yang mungkin timbul dalam perjalanan kegiatan perusahaan. 


\section{Daftar Pustaka}

Alvin A. Arens, Randal J. Elder, Mark S. Beasley, 2008. Auditing dan Jasa Assurance jilid 1 Edisi Kedua Belas. Alih Bahasa : Gina Gania. Erlangga, Jakarta

Alvin A. Arens, Randal J. Elder, Mark S. Beasley, 2008. Auditing dan Jasa Assurance jilid 2 Edisi Kedua Belas. Alih Bahasa : Gina Gania. Erlangga, Jakarta

Akmal., dan Marmah Hadi. 2010. EDP Audit. Erlangga, Jakarta

Charles W.M dan Eugene. 2010. Deteksi Kecurangan Akuntansi. PPM Manajemen, Jakarta

Drs. Amin Widjaja Tunggal, Ak., CPA.,MBA. 2010. Auditing Ikhtisar Teori Soal Jawab dan Kasus. Harvarindo, Jakarta

Drs. Amin Widjaja Tunggal, Ak, CPA, MBA, 2011. Pengantar Internal Auditing. Harvarindo, Jakarta

Drs. Amin Widjaja Tunggal., Ak., MBA. 2006. Financial Statement Auditing. Harvarindo, Jakarta

Drs. Amin Widjaja Tunggal., Ak.,CPA.,MBA. 2010. Dasar - dasar Audit Internal Pedoman Untuk Auditor Baru. Harvarindo, Jakarta

Drs. Amin Widjaja Tunggal., Ak.,CPA.,MBA. 2010. Ikhtisar Teori dan Tanya Jawab Audit Internal. Harvarindo, Jakarta

Drs. Amin Widjaja Tunggal., Ak.,MBA. 2008. Memahami Internal Auditing. Harvarindo, Jakarta

Drs. Amin Widjaja Tunggal, Ak.,CPA.,MBA. 2010. Teori dan Praktik Auditing. Harvarindo, Jakarta

Drs. Sayoto Gondodityoto.,MKom.,MM(SI).,MComm(IS).,PIA.,SE.,Ak. 2009. Pengelolaan Fungsi Audit Sistem Informasi. Mitra Wacana Media, Jakarta

Elder. J at all. 2008. Jasa Audit dan Assurance. Salemba Empat, Jakarta

Hall Singleton. 2007. Audit dan Assurance Teknologi Informasi. Edisi 2, Salemba Empat, Jakarta.

Ikatan Akuntan Indonesia Kompartemen Akuntan Publik. 2001. "Standar Profesional Akuntan Publik". Penerbit Salemba Empat, Jakarta

Intan Ghina. Hubungan Audit Operasional dengan efektivitas Pengendalian Penjualan http://intanghina.wordpress.com/hubungan peranan audit operasional dalam menunjang efektivitas sistem pengendalian intern penjualan

(Diakses 12 Oktober 2011)

PLN PT (Persero). Statistik PLN 2009. Jakarta 
Peranan Audit Internal untuk Meningkatkan Efisiensi Produksi Listrik dan Penerimaan Kas PLTD

Wilayah Distribusi Jawa Barat dan Banten Pada PT PLN (Persero)

PLN PT (Persero). Statistik PLN 2010. Jakarta

Riyanarto Sarno. 2009. Audit Sistem dan Teknologi Informasi. ITS Press, Surabaya

Sawyer, Lawrence B., Mortimer A Dittenhorfer, dan James H Scheiner. 2006. Audit Internal

Sawyer. Edisi Kelima. Alih Bahasa : Desi Adhariani. Buku I. Salemba Empat, Jakarta. 